Душан Ристић ${ }^{1}$

Душан Маринковић ${ }^{2}$

Одсек за социологију

Филозофски факултет

Универзитет у Новом Саду
Прегледни научни рад UDK 378:316"04/14“

Примљено: 7.12.2019.

Ревидирана верзија: 19.3.2020.

Одобрено за штампу: 20.3.2020.

DOI: https://doi.org/10.46630/gsoc.24.2020.03

\title{
ЗНАЊЕ У ЕВРОПИ СРЕДЊЕГ ВЕКА: ПРИЛОГ ГЕНЕАЛОГИЈИ УНИВЕРЗИТЕТА
}

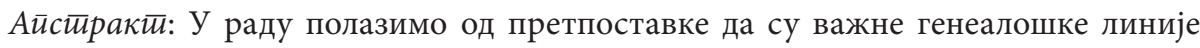
регионализације и институционализације знања, а посебно јавног и анонимног типа знања какво је научно, у Европи почеле да се конституишу захваљујући појави првих универзитета током 12. и 13. века. У простору европског средњовековља процес институционализације знања је, баш као и данас, неодвојив од политике, економије, географије и других друштвених чинилаца. У раду појаву универзитета и новог, анонимног и универзалног типа знања, повезујемо са питањем идентитета Европе тог доба. Иако су се први универзитети разликовали до извесне мере, они ипак имају нека битна заједничка обележја која већ тада постају препознатљива, а трају до данас. Наш циљ је да укажемо на то да генеалогију универзитета у Европи треба схватити како у контексту имагинаријума средњег века, тако и у оквиру друштвених околности у којима је он настајао. Посебну пажњу у том смислу придајемо сталешком типу организације феудалног друштва и „идеологији три реда“.
\end{abstract}

Кључне речи: знање, Европа, средњи век, универзитет, генеалогија

\section{Увод}

Средњи век није заједничко време неког јединственог простора - „наше“ заједничке европске географије и „нашег“ заједничког историјског времена. Иако је земља стратешки ресурс, не само економски и привредни, већ и друштвени, политички и правни, још увек нема „једне“ хомогене географије која би гарантовала глобалну перспективу. Још увек нема европског идентитета: политичког, културног и друштвеног, који би могао јасније да каже „ко смо ми, управо у овом тренутку историје“ (Fuko 2010), односно у заједничком времену и простору, историји и географији.

Упркос замишљеној представи реда, „[С]редњовековни поредак Европе био је (...) сигурно веома анархичан, ако му се поставе критеријуми једног

\footnotetext{
${ }^{1}$ risticd@ff.uns.ac.rs

${ }^{2}$ dusan.marinkovic@ff.uns.ac.rs
} 
нововековног предузећа које глатко функционише, али он, упркос свим ратовима и завадама, није био нихилистички, све док није изгубио своје темељно јединство уређења и смештања“ (Šmit 2011: 30). Управо концепт смешйана на којем инсистира Карл Шмит односи се на географију земље (не још и на географију мора), а та географија земље коју смо наследили - као науку - производ је политичких стратегија, борби и моћи, сталног европског покушаја да успостави јединство imperium-a и sacerdotium-a. Али, без „централистичког нагомилавања моћи у рукама једног човека“ (Šmit 2011: 36). Генеалогија Европе и европског идентитета је пре свега политичка географија расуйосиии, локалног и регионалног смешй $а ғ а$. У Европи ће историја дугог трајања географских структура: планина, низија, мора, висоравни (Brodel 2001) прећи у историју политичке географије или географије/политике 3 онога тренутка када отпочне процес смешйаға, расподела, цепања, освајања, заузимања, регионализације, премештања позиција - када отпочну људска колективна кретања и коњунктуре. Само је један „уистину географски појам“ - приметиће Фуко (2005: 94) архииела $\bar{z}^{4}$. Остали појмови су уобличени око шмитовског смешйана: поље, премештање, област, тло, регион, хоризонт.

Свакако, ни знање у предмодерној Европи, пре 17. века, још није смешйено. Као и народи, они изнутра, и они што долазе „споља“, и знање је дуго времена луталачко, мигрантско. Не само да долази са разних страна, „споља“, са Арапима преко Гибралтара, преко Византије, Сицилије и Јужне Италије, већ покушава унутар постојећег „расутог“ простора и да се смесии. Стога, у расутом простору европског средњовековља процес институционализације знања није одвојив од политике и географије. Том сраслом, неодвојивом појмовном пару географија/политика треба придодати знање, јер то је један од фундаменталних триједара преко којег је могуће дефинисати европски идентитет: географија/ политика/знање. „Институционални контекст знања је есенцијални део његове историје“ (Burke 2000: 32), а процес институционализације знања показује пре модерне епохе све одлике локалности, расутости и несталности смештања.

Иако се знање већ вековима чврсто повезује са науком, јер га је управо „локална“ европска пракса претворила у режим истине - да би га затим монополизовала, глобализовала и универзализовала - као полазну претпоставку треба узети његово шире одређење, уз „извесност да су феномени стварни и да поседују извесне карактеристике“ (Berger and Luckmann 1991: 13). За социологе, „знање укључује све могуће типове познате у прошлим и садашњим друшт-

\footnotetext{
${ }^{3}$ У смислу њихове неодвојивости.

${ }^{4}$ Иако Фуко не објашњава зашто је појам архипелага једини уистину географски појам, може се претпоставити да је то управо због тога што се не ради о географији земље или о номосу землье, већ о расутости усред отвореног мора. Јер море се дуго времена не заузима; на њему дуго времена не може да се успостави номос. Како примећује Шмит, „сви предглобални поретци били су у суштини койнени, чак и када су у себи садржавали владавину над морем и таласократије (2011: 20). Такође, с обзиром да над водом дуго не може да се успостави номос, она није ни йойос у правом смислу речи, већ више хеиееройойос који није простор смешйаға а тиме и борби, подела, граница, стратегија, политике и географије.
} 
вима“, односно „све што може да се сматра знањем“ (McCarthy 1996: 16). При томе, извесности упућује на то да знање не мора нужно да буде знағе истине у научном или филозофском смислу, већ и знаюе смисла које обезбеђује основну интерпретативну и симболичку схему у односу према ономе што се назива сйварносй. Знање је и врста „отпора“ контингентности света догађаја за које процењујемо да не зависе од нас. Постоји снажни „антиципаторни потенцијал“ у ономе што се назива знањем.

\section{Знање и друштвена обележја феудалног поретка}

Знање представља производ историјских и друштвених околности и увек се може повезати са различитим регистрима у којима настаје, односно са начинима његове легитимизације (Weiler 2009). Ти различити регистри уз помоћ којих се знање дефинише указују на оно што је већ приметио Мишел Фуко (1990), а то је да се ниједно знање не уобличава без неког система комуникације, регистровања, акумулације, померања. Дакле, знање није независно од времена, (локалности) простора, институција и пракси у којима настаје. Релационалност знања карактеристично је обележје и научног знања, које „далеко од тога да представља хладни и индиферентни образац апсолутне објективности“ (Latour 2007: 16).

У овом раду полазимо од претпоставке да су важне генеалошке линије регионализације знања, а посебно научног знања, као јавног и анонимног, у Европи почеле да се појављују захваљујући његовој постепеној институционализацији. То се пре свега односи на појаву првих универзитета, почевши од 12. века.

Када је у питању европски континент, задатак регионалне географије знања, гео-епистемолошког приступа (Маринковић et al. 2014), јесте да покаже како је знање конструисано, шта су прихватљиви начини објашњења стварности и како се различите тврдње о њој стабилизују и оправдавају током историје Евpoпе (Livingstone 2003: 88). Знање увек има геоепистемолошке аспекте, улоге и спацијализоване форме, односно просторе у којима је смешиеено и захваљујући којима су дистрибуирани говори, технологије и моћ (Marinković i Ristić, 2016). То значи да оно није аутономно, већ настаје захваљујући низовима или слојевима (и дисконтинуитетима) временско-просторних артикулација друштвених пракси.

Поред тога, идеал „јавног знања“, према мишљењу Питера Берка, почео је да се остварује у раном периоду модерности Европе, а питање „које врсте знања су могле да буду јавне изазива контроверзе и на њега је одговорено на различите начине у различитим генерацијама и у различитим деловима Европе“ (Burke 2000: 83).

За истраживање везе знања и простора значајан је оквир генеалогије, као историје смисла. Генеалошки оквир истраживања има за циљ да идентификује праксе у којима се знање укршта са другим друштвеним појавама, попут простopa (Ristić and Marinković 2016; Marinković and Ristić 2019). 
Просторне димензије знања, дакле, важне су и указују на фрагментиран и регионализован карактер знања. Идентитет је последица специфичног историјског развоја и пракси. Идентитети се такође, стварају захваљујући знањима и дискурсима, с обзиром да имају и наративну димензију (Delanty and Rumford 2005: 51). Идентитете можемо да анализирамо и као производе специфичних „стратегија исказивања“ у оквиру „игре посебних модалитета моћи“, те су они зато и производи „разлике и искључивања“, односно знак „идентичног, природно-конституисаног јединства“ (Hall 1996: 4). Њихову геоепистемологију могуће је истраживати у оквиру триједра односа знања (дискурса), моћи и простора (Marinković and Ristić 2016; Marinković i Ristić, 2016).

И сам термин „Европа“ или „европски идентитет“ нису „непроменљиве историјске и географске датости, него пре облик историјске и мобилне матрице“ (Wintle 2013: 10). Дуго времена у Европи, у процесу смешйања, идентитет и знање су или номадски или локално ситуирани. Дуго времена, Европа је просторни идентитет засеока, забачених и разбацаних села. Све до 11. можда и 12. века то је географија неискрчених шума, зараслих поља, тешко проходних планина, дивљих и опасних река, још опаснијих мора на којима и моћне йаласокрайије не могу да успоставе номос. Дуго времена је то била географија зараслих римских путева, урушених мостова, разграђених позоришта и амфитеатара. То је предео избледелих структура пређашње урбане географије Рима. Тек понегде - „град“: често сабијен у димензије напуштених амфитеатара - град-амфитетар, град-палата, град-циркус, град-хиподром, град-позориште. Још се не назире сила која ће тој географији расутости дати једно име - Европа - у којем ће се, без обзира на мноштво локалних и парохијалних разлика препознати већина - на Балтику, Медитерану, атлантским обалама, Карпатима или Уралу. Још увек нема номоса над европским тлом који ће обезбедити међународно право, иако Respublica Christiana покушава да наметне један просторни поредак као „међународно правно јединство европског средњег века“ (Шмит 2011: 31).

Датуми, односно битни догађаји који се везују за одређене периоде дугог средњег века и промене у друштвеним обележјима феудалног поретка и данас изазивају контроверзе. ${ }^{6}$ О историјским и друштвеним приликама током епохе феудализма, посебно оним које су обележавале просторе данашње Западне Европе већ је написана обимна литература, међу којом се могу издвојити истакнути представници француске историјске школе (Bloch 2001; Диби 2001; 2007a; 2007b; Duby 2007; Ле Гоф 2010; Le Goff 1974; 2009; Ладири, 1991; Бродел 2001;

\footnotetext{
${ }^{5}$ Сложеница од грчког $\theta \dot{\lambda} \lambda \alpha \sigma \sigma \alpha$ (thalassa) - more. У словенским језицима још се задржала реч йалас.

${ }^{6}$ Концепт, односно појам који је незаобилазан у студијама које се баве средњим веком и који је по неким ауторима сувише поједностављен и не одражава шароликост уређења самих друштава, односно, не обухвата различите начине на који је средњи век био устројен. Иако се истичу многе предности овог појма који има изграђен легитимитет и у академској и у колоквијалној употреби, критике и ограничења које он намеће и даље су предмет расправа историчара. О томе видети, на пример: Brown 1974.
} 
Делимо 1987; 2007; Февр 2015; Миноа 1994; 2008; Milenković 2016). У једној од најзначајнијих књига о тој проблематици - Феудалном друшивву, Марк Блок закључује да би била „заблуда расправљати о 'феудалној цивилизацији’ као о целини која је у времену недељива и јединствена" (Bloch 2001: 69). Другачије речено, време и простор европског средњовековља показују расуйостии и регионалне локалносиии (Маринковић, et al. 2014).

Историчар Јохан Хојзинга писао је да се епоха „правог феудализма“ и цветања витештва завршила у 13. веку, након чега долази „градско-кнежевски период“ средњег века у којем су „трговачка моћ грађанства и на њој заснована новчана моћ кнежева владајући фактори у држави и друштву“ (Хојзинга 1991: 73). Феудалност је подразумевала и комадање власти: „Покрет који ју је обликовао био је на делу од краја 9. века, када су у областима које су улазиле у састав Француске каролиншки краљеви престали да држе на узди своје племство“ (Dibi 2007a: 84). Блок такође сматра да је током феудализма могуће издвојити два узастопна раздобља, која су међу собом веома различита. Посебно се, у његовој интерпретацији, наглашавају промене током 11. века, промене које нису довеле до неког прелома, али су захватиле „редом готово све кривуље друштвене активности“ (Bloch 2001: 69). Те промене настављене су и током 12. века, у чему је посебан друштвени значај имала појава првих универзитета, чему ћемо у другом делу рада посветити посебну пажњу.

Друштвена обележја феудалног поретка ипак, јесу оно што је одиграло кључну улогу у процесима који су довели до институционализације знања и настанка првих универзитета на тлу Западне Европе. Међутим, на овом месту не можемо се бавити ширим димензијама и посебним одликама које су биле карактеристичне за различита друштва на тлу Европе. Оно на шта посебно хоћемо да скренемо пажњу јесте да је у трансформацијама феудалних друштава̂ Европе важну улогу имао и универзитет - прво као идеја, а затим и као институција. ${ }^{7}$

Подела друштва на сталеже у средњем веку, сматра Хојзинга, такође је важна, јер све до сржи прожима сва теолошка и политичка разматрања. Та подела се не треба искључиво схватити кроз „уобичајено тројство“: свештенство, племство и трећи сталеж. Јер, појам сйалежа у том контексту има већу вредност и шире значење, а поред тога, „свако груписање, свака функција, сваки позив посматра се као сталеж, тако да поред поделе друштва на три сталежа може да се јави подела на дванаест" (Хојзинга 1991: 74). У средњовековном имагинаријуму, појмови сйалежа и реда $a^{8}$ су спојени са свешћу да свака од друштвених група „представља нешто што је Бог одредио, један орган у светској грађевини, нешто што је исто тако битно и исто тако хијерархијски часно као што су небески престоли и силе хијерархије анђела“ (Хојзинга 1991: 74-75). У таквој констелацији, слика коју су људи стварали о себи и одређена функција која је произилазила из сталежа у држави и друштву у којем су живели, произилазила

\footnotetext{
${ }^{7}$ О утицају кулитурних факӣора на настанак феудализма у средњем веку видети: Duby 1968.

${ }^{8}$ О два значења речи ред (лат. Ordo) у то време, видети: Duby 2007: 93.
} 
је више из одблеска Божје идеје него из корисности. Таква слика друштвеног живота била је више статична него динамична. Јер, Бог је створио прост народ да ради и обрађује земљу и тргује, свештенство је ту за дела вере, а племство да диже врлину и брине о правди - тако да другима буде узор. Највиши задатак у држави (одбрана цркве, ширење вере, заштита народа и сл.) поверен је племству. Са друге стране, „трећи сталеж још никако није коригован у правцу стварности“ (Хојзинга 1991: 75). За схватање улога које произлазе из сталежа, важно је разумети сам појам реда (ordo). Постојало је више различитих редова: ред оних који заповедају, ред поданика, ред богатих, ред сиромашних, ред старих, ред младих, итд. (Duby 2007: 94). Но, реч ordo „ипак не означава само сваки поједини од њих, она означава такође и то обнашање власти које их разлучује и усклађује. Унутар свакога реда постоје различити задаци, различите службе, хијерархијски поредани. Bећ се наслућује тројност“ (Duby 2007: 95).

Подела средњовековних друштава на три реда, тј. оне који моле и говоре (oratores), оне који ратују (bellatores) и оне који раде (laboratores), јесте одраз перцепције средњовековних структура власти, која није настала као „резултат жеље владајућих елита за повећањем утицаја и контроле над поданицима, него као резултат њихових настојања за одржањем постојећега стања, које је уредио бог, а које је непрестано нарушавано непримереним понашањем чланова заједнице“ (Роріс́ 2007: 242). То би онда, могло да значи да је концепт и идеја о подели на три реда у друштвима средњег века у основи конструкт који су развиле тадашње владајуће елите и „који није представљао средњовековну стварност, али је из ње произилазио и чинио је слику архетипскога друштва каквом су елите тежиле“ (Рopić 2007: 242).

Несумњиво је постојање механизама кроз које су средњовековне владајуће класе и владари, односно сталежи, успевали у својим настојањима да „наметну“ одређену слику стварности, односно одређени политички поредак и краљевску власт као готово природно стање ствари. Свака представа о друштвеним односима у средњем веку, нужно је тражила ослонац у неким фундаменталним текстовима хришћанства (Duby 1986: 2066) 9 . Тако је и средњовековна власт, барем у теорији, тежила извршењу „божанског наума“. Таква димензија средњовековне власти и моћи била је сумирана у познатом изразу rex Dei gratia, а потврђивала се бискупским помазањем и посвећењем особе владара. Већ та је чињеница била довољна да осигура политички ауторитет и легитимитет средњовековним владарима (Роріс́ 2007: 247).

Краљевска власт успевала је, без обзира на свргнућа владара и њихове смене, да се одржи кроз читаво раздобље средњег века и раномодерног доба,

\footnotetext{
${ }^{9}$ Пишући о „витешкој мисли“ у средњем веку, Хојзинга наводи да је средњовековни поглед могао једном животном идеалу дати племенито место само тако ако га постави у однос према побожности и врлини (Хојзинга 1991: 87). Чак и у свакодневном животу, „средњовековни човек мисли на исти начин као и у теологији. Темељ је и овде и тамо онај архитектонски идеализам који је схоластика називала реализмом (Хојзинга 1991: 308). У свим стварима тражена је „моралност“, односно поука која се у њима налазила, тражен је њихов морални значај, јер је он био најбитнији (Хојзинга 1991: 310).
} 
све до Француске револуције. Имагинаријум који је „окружује“ настао је дисеминацијом различитих симбола и њихових репрезентација. Начин на који су се културни обрасци, као темељи симболичког универзума ширили по социјалном ткиву током тог раздобља историје, на одличан начин објаснио је Жорж Диби (Duby 1968). Он сматра да су они који су у хришћанском друштву, у Европи 11. века, били кадри да размишљају, да своје мишљење обликују, да га изразе тако да не буде брзо заборављено - а то су били црквене вође, успели су да створе један „идеолошки модел“ (Duby 1986: 2074). Тај модел је израз оне схеме која је делила људе на три категорије, односно сталежа: на стручњаке за молитву, стручњаке за борбу, те стручњаке за производњу, што су за њу сељаци (Duby 1986: 2074). Идеолошка схема о три реда, по мишљењу Дибија, верно је одражавала глобалне структуре аграрног друштва које је на неке „пренело бригу за своју заштиту, кроз употребу оружја против познатих агресора, кроз вербално оружје против мрачних сила с оне стране“ (Duby 1986: 2074). И даље, та подела артикулише колико економске структуре, толико и идеолошку позадину. Јер, „кметови производе богатство; сер се тако легитимно богати, али не задржава то богатство за себе; мора да га расподели читавом витешком свету, а најпре међу омладином. Двор је орган те расподеле - што ће двор краља Француске остати све до 1789“ (Dibi 2007a: 87). Захваљујући таквој интерпретацији стварности, прикривана је напетост међу исте те три друштвене категорије под плаштом уравнотежења размене различитих услуга, док се стварне неједнакости оправдавају обављањем ових услуга, односно специјализованих функција које обављају различити сталежи. ${ }^{10}$

Историјски документи, како пише Жорж Диби, откривају „само оне идеологије које одговарају интересима и веровањима водећих класа, јер су само оне имале могућност стварања непролазних културних добара чији су трагови подобни за повијесну анализу“ (Duby 1986: 2070). Смислено је зато поставити питање стварног домета „владајуће идеологије“ и граница имагинаријума средњег века, с обзиром на претпоставку да потпуна „колонизација свести“ свих друштвених сталежа у истој мери није била могућа, иако је поредак којим је доминирала оваква слика света са мање или више успеха одржаван неколико векова. „Популарне идеологије“ - тако Диби назива оне алтернативне визије света које потичу из сталежа који нису имали власт и нису имали приступ „културним инструментима“, па самим тим нису ни могли оставити значајнијег историјског трага.

Ипак, идеологије јесу „омотачи“, односно системи представа чији је циљ да ојачају и прибаве оправдање понашању људи и као такве, оне јесу предмет историје. Промишљеност у истраживањима ових проблема налаже одређивање ширине дистанци које, у свакоме друштву, понашање људи дели од њи-

\footnotetext{
${ }^{10}$ На основама Димезилове идеје о три реда, односно три сталежа у средњем веку, Ле Гоф сугерише могућност истраживања стварања универзитетске власти. Тако и у трима властима - црквеној, краљевској и универзитетској, препознаје се систем тројне власти: „Уз верску и политичкоратничку функцију, остварена је и образовна, која је у почетку само вид треће, функције обиља, продуктивне привреде“ (Le Goff 2009: 13).
} 
хових духовних представа или система вредности према којима се они вољно односе (Duby 1986: 2073). Вредне су зато критичке опаске Пола Вена који сматра да су понашања непосредније одређена идеолошким мотивима у склопу успостављања друштвених веза, унутар институција. Управо су оне подручје на које историчар идеологија најпре треба да примени своја запажања (Duby 1986: 2073; такође и: Ven 2013). Коначно, сматра Диби, „треба промотрити дуготрајни опстанак овога идеологијског система, кроз његова сукцесивна прилагођавања, те испитати његов утицај на развитак целине друштвених односа“ (Duby 1986: 2077).

\section{Појава универзитета̂ и њихове карактеристике}

Први универзитети који су у складу са прописима постали организована и колективна целина, потекли су из манастирских и катедралских школа ${ }^{11}$. Они се појављују у Европи још крајем 11. века, најпре у Болоњи и Паризу. Жак Ле Гоф је настанак првих универзитета повезао са појавом интелектуалаца у новонастајућим градовима 12. века (Le Goff 2009). Подела рада, нове установе и заједнички простор хришћанства који више није толико географски и политички расцепкан као у раном средњем веку, јесу обележја новог „интелектуалног пејзажа“ западног хришћанства на прелазу из 12. у 13. век. То је период и контекст настанка првих универзитета. Појава интелектуалца у том периоду, претпостављала је поделу рада у граду, исто „као што настанак универзитетских установа претпоставља заједнички културни простор у којем нове 'катедрале знања' могу слободно колати, напредовати и сучељавати се“ (Le Goff 2009: 11). 12. век није био само век оживљавања интереса за учење, већ и век у којем су настајале нове институције. Тај век је почео са монашким и катедралским школама, а завршио са раним универзитетима (Haskins 1968: 368). У том смислу, он представља век у којем почиње процес институционализације знања и високог образовања. Универзитети су, сматра Чарлс Хоскинс, настали не зато што није постојало довољно учености на тлу Европе, већ природно, са експанзијом знања у том периоду: „Интелектуална револуција и институционална револуција ишле су руку под руку“ (Haskins 1968: 368). Раздобље стварања и развоја универзитета део је доба развоја и неке врсте специјализације јавних служби у градовима средњег века.

У новонастајућим градовима, односно комунама, организују се у све већем броју корпорације - гилде и цехови, које представљају удружења занатлија настала ради заштите права и економских интереса. На трагу тог модела настају и универзитетске „корпорације“. Организовале су се постепено, а често су тек накнадно потврђиване статутима. У литератури се често истичу

\footnotetext{
${ }^{11}$ Први универзитети, како наводи Чарлс Хоскинс, нису имали посебно изграђене зграде, већ су били део цркава - примери могу бити црква San-Julien-de Pauvre из Париза у којој су се одржавали универзитетски сусрети, или нешто „амбициозније учионице“ из Болоње. Видети: Haskins 1979: 22, 45.
} 
два модела универзитета који су карактеристични за јужну (Болоња) и север-

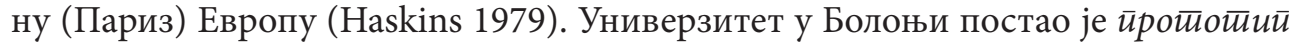
универзитета насталих као удружења студената, који су имали главну улогу и запошљавали професоре на основу уговора (Haskins 1979: 9). Са друге стране, односно насупрот томе, универзитет у Паризу представљао је модел за univesitas professorum, удружење професора који су имали водећу улогу (Haskins 1979: 19).

Средњовековни универзитети као „корпорације професионалног реда“, настојали су да задобију школски монопол, то јест пре свега, монопол додељивања академских титула. То их доводи у сукоб са црквеним властима. Локални бискупи настоје да задрже надзор на том пољу, сматрајући да је подучавање ствар цркве и да су преношење знања, подучавање, као уосталом и култура, питање вере. Период стицања аутономности ових, али и каснијих универзитетских корпорација варирао је и није пролазио без сукоба са властима, па чак и грађанима (Le Goff 2009: 122-123). Значајно је у том смислу напоменути да је постојала велика разноликост у начину оснивања и озакоњења појединих универзитета. Једна од подела универзитета тог доба их дели на: градске - који су се највише оснивали у Италији; капитолске - који су се развијали из катедралских школа; и државне, који се појављују нешто касније, а оснивају их немачко-римски цареви и други владари, нарочито у Шпанији (Милић 1986: 584). Без обзира на различита обележја самог настанка и устројства универзитета, они су у том добу представљали заједнице професора и студената и били су организовани на основу владарске или црквене привилегије чији је садржај био даривање аутономије (Le Goff 2009: 123; Haskins 1979: 49).

Корпоративизам и цеховска организација јесу главна обележја која разликују средњовековне универзитете од ранијих образовних режима. Администрације у модерном смислу наравно, није било, али је добар део времена одлазио на различите врсте универзитетских састанака (Haskins 1979: 50). Као корпорације, средњовековни универзитети су дакле, сем потраживања школског монопола, потраживали и правну аутономију. То је, што се државних (градских) власти тицало, било прихватљиво. Јер, „у оној мери у којој универзитет, као и свака корпорација, има за циљ да контролише школски занат, државне власти виде углавном само предности те организације йрофесионалног реда која се сврстава у општи јавни поредак“ (Ле Гоф 1997: 200). Но, „као мотив за сукобе остаје непоштовање универзитетског форума од стране градских или краљевских службеника: студенти и професори су често хапшени без обзира према статутима, изузимани су из универзитетске јурисдикције“ (Ле Гоф 1997: 201).

По мишљењу Ле Гофа, универзитетски цех се истиче својом посебношћу, односно неодређеним положајем у друштву, што га баца и у кризе његове структуре (Le Goff 2009: 125). Прво, због тога што је ипак у питању црквени цех - јер је, без обзира на све већи број „чистих лаика“ на универзитету, он био у надлежности црквених јурисдикција. Поред тога, он је био интернацио- 
налан, како по чланству (јер су учитељи и ђаци долазили из разних земаља) тако и по начину рада: знање не познаје границе, a licentia ubique docendi коју су по статуту могли да уживају сви који су дипломирали на неком од великих универзитета, давала је право да се поучава посвуда (Le Goff 2009: 126-127). И даље, „он нема, попут других цехова, монопол на локално тржиште. Његова је област хришћанство. Самим тим он прелази оквире града у којем је настао (...). Вероватно је зато морао продрети у све сталеже и друштвене групе. Вероватно је зато морао издати све и свакога. Он је Тројански коњ за Цркву, за Државу, за Град“ (Le Goff 2009: 127).

На самом почетку, универзитетске корпорације нашле су се у противречном односу са друштвеном заједницом у оквиру које су се развијале. Из таквог односа који је био бременит сукобима, временом се успоставља принцип аутономије, као суштински принцип функционисања ове институције. Овим „обртницима духа“, како сматра Ле Гоф, „који су увучени у процват градова у 12. веку, још само преостаје да се, као круна градске самоуправе, организују у велики цеховски покрет. Из цехова учитеља и ђака дословце ће се изродити универзитети. То ће се догодити у 13. веку“ (Le Goff 2009: 113).

Процес институционализације универзитета је текао уз мање или веће друштвене и политичке препреке и проблеме, током читавог једног века или чак и дуже. Он је оличен и озваничен у папским булама, црквеним и политичким декретима владара, али су свакако, битну димензију за само функционисање универзитета у средњем веку и разумевање његовог друштвеног значаја чинили и документи који су настајали у њиховом окриљу - статути, програми (curriculum), уговори и сл. Ле Гоф зато сматра да су статути средњовековних универзитета изражавали не само њихову цеховску природу, већ и интелектуалну и моралну климу доба у којем су настајали (Le Goff 2009: 137). И наравно, захваљујући тим документима, могуће су историјске реконструкције.

Врло важно питање, без којег процес институционализације знања оличен у универзитетима 12. и 13. века не може бити у потпуности објашњен, јесте питање које је поставио управо Ле Гоф: Какву свести има средюовековни универзитеиеи о себи? Одговори на ово питање за циљ имају да укажу на проблем „освешћења“, који представља једно од кључних и веома тешких проблема историје (Ле Гоф 1997: 172).

У том контексту је важно и питање о представама о сврси и функцији универзитета („самосвести“), које су имали они који су на универзитетима били ангажовани. То је важно да би се назрели трагови стила, начина мишљења и преношења знања карактеристичног за то доба. Одговор на то питање води ка објашњењу универзитета као „цеха“, односно као корпорације и друштвене институције. Ле Гоф сматра да је важно утврдити повлашћена поља посматрања - чак и експериментисања: апаратуре и методе па, на крају, препознати - можда? - један основни критеријум за схватање тог суштинског феномена: пресудног тренутка у коме су сагледане инфраструктуре, у коме се препознаје група, потврђује и „рађа“ универзитет по други пут, одлучно, кроз свест о своме пореклу (Le Gof 1997: 172). 
Сигурно је да институционални образац средњовековних универзитета није био једнообразан. Примера ради, теологија и филозофија нису биле језгро свих, чак и неких врло познатих универзитета: у медицинској школи у Салерну (11. век) није постојала ни теолошка ни филозофска школа, а такође ни у Монпељеу (12. век), где је филозофска школа настала век касније, а статус универзитета добијен тек у 15. веку. Ова два универзитета су имала водеће место у студијама медицине, као што су Париз и Оксфорд предњачили у теологији и филозофији, а Болоња у области права. ${ }^{12}$ Због „специјализације“, универзитети нису ни могли да у подједнакој мери израстају из теолошких и општеобразовно усмерених ранијих катедралних школа, а још мање из манастирских, већ су неки настајали и независно од тих школа (Милић 1986: 583).

Два такође важна елемента препознавања посебности универзитета произлазе их економских основа и „професионалног морала“. Већ смо напоменули да је цеховска организација, односно корпоративност била економска подлога организације универзитета, док је питање професионалног морала универзитетлија део шире „духовне климе“, која се опет, такође може интерпретирати и објашњавати у контексту религијске слике света (Weltanschauung) тог доба, али и промена на нивоу поделе рада, развоја градова, економских преструктурирања и сл. Држећи се примера Париза, Ле Гоф наводи схватање Абелара о посебности нове групе учењака којој је он припадао. За ту групу, посвећење је етикеција; она развија посебан морал и потребу за издвајањем, признањем сопственог рада и занимања (...) да би на крају, делатности и трагања нових студената и зналаца, поред плате (у било ком облику) имали и славу, односно престиж (Ле Гоф 1997: 175). Грађани, „нови интелектуалци“ како их назива Ле Гоф, људи су од заната. Они морају попут трговаца - јер они су „продавци речи“ као што су ови „продавци времена“ - да сруше уврежени клише по којем се знање не сме продавати јер је оно дар од Бога (Le Goff 2009: 11). Сем тога, интелектуалци као стручњаци, „затрпавају се хрпом помагала“, чиме се све више удаљавају од свештеника из раног средњег века, којима је за њихово углавном усмено поучавање био потребан врло скроман прибор за писање ретких рукописа (Ле Гоф 2009: 142).

Важно питање које такође открива елементе институционализације универзитета је и питање смене универзитетског кадра. Највећи део ђака и учитеља махом су млади племићи, убрзо и млади „грађани“. Па ипак, универзитети су омогућавали успон на друштвеној лествици и одређеном броју сиромашнијих. Формирање универзитетске олигархије, односно „касте“ (сталежа), праћено је доделом једне од битних ознака племства - наследности. Сем тога, Марк Блок је уочио да је сталеж универзитетлија у жељи да се устроји као аристократија, радио оно што обично раде групе и појединци кад желе да уђу у племство: почели су да прихватају аристократски начин живота (према: Ле Гоф 2009: 199).

\footnotetext{
${ }^{12}$ База образовања у раном средњем веку, састојала се од тзв. седам слободних вештина (septem artes liberales). Граматика, реторика и логика биле су груписане у trivium, док су аритметика, геометрија, астрономија и музика чинили quadrivium. Више о курикулумима у том периоду видети у: Haskins 1979: 27-39.
} 
Економској основи и изградњи аутономије универзитета погодовала је ситуација у којој је црква, у то доба развијена институција, тражила образоване чиновнике. Поред тога, нарастајући обим градских јавних послова и трговине могао је да запосли и друге образоване људе који су знали да рачунају и воде књиге (Haskins 1979: 37). То је добра илустрација чињенице да знање које је стварано и преношено путем новонастајућих институција није настајало „само по себи“, већ из разлога нарастајуће друштвене потребе за њим. ${ }^{13}$

Дванаести век је ипак, сматра Ле Гоф, још увек пун симбола. Међутим, појава универзитета језичак на ваги окреће према рационалној науци (Le Goff 2009: 96). Сва битна обележја универзитета као институције која и данас познајемо - у нешто измењеном облику, настају у периоду 12. и 13. века на тлу западне Европе. Само име универзитета, као ипum veruma, односно асоцијације ученика и професора који пристају на један нови начин живота (common life of learning), појам курикулума као основе студирања, организација и подела универзитета на факултете, статути као основни документи којим се уређује и утврђује начин рада, итд. све се то јављало у наведеном периоду и у организацији рада универзитета. Управо је на нивоу трајања институције могуће најјасније уочити елементе универзитетске традиције, сматра Чарлс Хоскинс (Haskins 1979: 24). Иако су рудиментарна обележја, која и данас чине окосницу ове институције, била присутна још у 12. веку, бар у основном смислу, друштвене функције и улога универзитета се временом свакако мењала и усложњавала.

\section{Закључна разматрања}

У раду смо истакли неке од важних елемената генеалогије универзитета у средњем веку, институције у којој је знање почело систематски да се ствара и шири. Могуће је свакако, посебно разматрати и питање „концептуалне револуције“ у мишљењу, односно у којој мери је „јерес науке“ која се тада ствара на универзитету, уз нове методе учења и преношења знања (схоластика, дијалектика, реторика) допринела променама у самом начину мишљења (видети: Stiefel 1977).

Пре појаве првих универзитета и профилисања посебног друштвеног слоја који Жак Ле Гоф назива интелектуалцима средњег века, проучавање и истраживање, односно само сазнавање, било је искључиво у вези са црквом и вером. Управо је појава универзитета отворила процес делегитимизације црквених учења као легитимних облика знања у средњовековном друштву, отварајући и простор за развој знања као рационалног дискурса. Знања која су почела да се обликују на универзитетима, иако с почетка још увек у окриљу

\footnotetext{
${ }^{13}$ Писање књига о праву и теологији била је последица све већег броја универзитетских предавања. Зато не треба да чуди, сматра Хоскинс, да су и сами универзитети своју финансијску самосталност почели да изграђују трговином књига, односно издавачким пословањем (Haskins 1979: 38).
} 
цркава, како интелектуално тако и физички, настају захваљујући раду и развоју мишљења. И како каже историчар: „Да бисмо разумели уређење људских друштава и да бисмо уочили снаге које утичу на њихово преображавање, једнаку пажњу ваља посветити духовним појавама, чије је деловање исто тако детерминишуће, као и оно економских и демографских. Јер људи своје деловање не уређују према њиховом збиљском стању, већ према замисли коју о њима стварају и која их никада верно не одражава“ (Duby 1986: 2065).

Улога „идеологије“ у феудализму била је да осигура акумулацију и присвајање власништва који су опет имали ефекта на стварање извесне политичке кохерентности у оквиру доминатних класа (Abercrombie and Turner 1978: 150). Ипак, у феудализму и раном капитализму постоји мало убедљивих доказа који би ишли у прилог тврдњи да су потчињене класе прихватале доминантну идеологију. Пре се може говорити о томе да доминантна идеологија највећег значаја има за доминантне класе, да представља и изражава смисао њиховог погледа на свет и да се не „шири“ толико по социјалном ткиву, међу депривираним друштвеним класама (Abercrombie and Turner 1978: 159). Доминантна идеологија у феудализму је зато, сматрају Аберкромби и Тарнер, била неки облик „културног механизма“ који је имао улогу да заштити саму доминантну класу (односно неколико слојева који се преплићу у њој) од претњи међукласних сукоба (Abercrombie and Turner 1978: 165). Тај културни механизам оличен је и у „идеологији три реда“ о којој је било речи у овом раду. Жорж Диби је писао о томе како су се управо у феудалном друштву, путем образаца културе, схватања виших класа ширила корак по корак, према депривираним друштвеним групама (Duby 1968: 3; Duby 2007: 107). Феномен „популаризације аристократских модела“ (културе), како пише Диби, није био једносмеран процес. Прихватање и имитација аристократских модела и ставова од стране нижих друштвених класа, допринели су и томе да друштвене елите прихвате одређене културне обрасце који потичу из тих класа и да модификују сопствена схватања. Зато је, сматра Диби, циљ да се схвати како је популаризација аристократских културних модела, као детерминишућа мотивациона сила у културној историји, довела до тога да се успостави двосмерна комуникација култура̂ на различитим друштвеним нивоима (Duby 1968: 5).

Коначно, појава првих универзитета на тлу западне Европе представљала је и израз имагинаријума средњег века - укључујући и елементе о којима није било речи у овом раду - на пример, значај трговине и утицаја знања која су „стизала са Истока“, из арапског света. И сва та „полиморфна знања“ су на тлу Европе „префабрикована“ у једно анонимно и универзално знање доступно свима. Европа је, како пише Фуко, у том смислу успела да артикулише начин универзалног стицања и саопштавања знања, односно „бесконачну слободну размену говора“" (Fuko 2007).

Коначно, Европа је, насупрот знању које је „заробљено у ритуалне праксе, у структуру свакодневице која се за тренутак прекида церемонијалом /институционализацијом“, понудила „деритуализацију знања и пракси његовог про- 
извођења и преношења“ (Маринковић et al. 2014). То показује и поређење које наводи Питер Берк (Burke 2000: 49-50) између успостављања раног европског модела знања и медреса̂ муслиманског света, где су ученици стицали неке врсте личних дозвола (ијаза), а не дипломе које издаје институција. Било је важно код ког̈а је ученик учио, а не г̇де је учио (Маринковић et al. 2014), што ће рећи да су студенти „лутали“ од учитеља до учитеља, а не од универзитета до универзитета - као у Европи средњег века.

\section{Литература}

Abercrombie, N. and Turner, B.S. (1978) “The Dominant Ideology Thesis”, The British Journal of Sociology 29(2): 149-170.

Berger, P. L. and Luckmann, T. (1991) The Social Construction of Reality. London: Penguin Books.

Bloch, M. (2001) Feudalno društvo. Zagreb: Golden Marketing.

Brodel, F. (2001) Mediteran i mediteranski svet u doba Filipa II. Beograd: Geopoetika.

Brown, E.A.R. (1974) "The Tyranny of a Construct: Feudalism and Historians of Medieval Europe”, The American Historical Review 79(4): 1063-1088.

Burke, P. (2000) A Social History of Knowledge. Cambridge: Polity.

Delanty, G. and Rumford, C. (2005) Rethinking Europe: Social theory and the implications of Europeanization. London and New York: Routledge.

Делимо, Ж. (1987) Сӣрах на Зайаду. Нови Сад: Издавачка књижарница Зорана Стојановића.

Delimo, Ž. (2007) Civilizacija renesanse. Sremski Karlovci: Izdavačka knjižarnica Zorana Stojanovića.

Dibi, Ž. (2001) Umetnost i društvo u srednjem veku. Beograd: Clio.

Dibi, Ž. (2007a) „Roman o ruži“, Žurnal za sociologiju 5: 82-105.

Dibi, Ž. (2007b) „Istorija sistema vrednosti“, Žurnal za sociologiju 5: 105-118.

Duby, G. (1968) “The Diffusion of Cultural Patterns in Feudal Society”, PastæPresent, 39: $3-10$.

Duby, G. (1986) „Socijalna historija i društvene ideologije“, Naše Teme 20(12): 20652078. Zagreb.

Duby, G. (2007) Tri reda ili imaginarij feudalizma. Zagreb: Golden Marketing, Tehnička knjiga.

Fevr, L. (2015) Ljubav sveta, ljubav profana: oko Heptamerona. Novi Sad: Mediterran Publishing.

Fuko, M. (1990) Predavanja. Novi Sad: Bratstvo - Jedinstvo.

Фуко, М. (2005) „Питања Мишелу Фукоу о географији“ у Мишел Фуко 1984-2004 (П. Миленковић и Д. Маринковић, прир.), 91-100 Нови Сад: ВСА.

Fuko, M. (2007) Poredak diskursa. Loznica: Karpos.

Fuko, M. (2010) „Niče, genealogija, istorija“ u Mišel Fuko: Spisi i razgovori. Beograd: 
Fedon.

Hall, S. (1996) "Who Needs 'Identity'?" in Questions of Cultural Identity. London: Sage Publications.

Haskins, C.H. (1968) The Renaissance of the $12^{\text {th }}$ Century. Cleveland, New York: Meridian Books.

Haskins, C.H. (1979) The Rise of Universities. Ithaca and London: Cornell University Press.

Хојзинга, J. (1991) Јесен Средюег̈а века. Нови Сад: Матица Српска.

Ladiri, E. L. R. (1991) Montaju: oksitansko selo od 1294. do 1324. Sremski Karlovci: Izdavačka knjižarnica Zorana Stojanovića.

Latour, B. (2007) “The Recall of Modernity: Anthropological Approaches”, Cultural Studies Review 13(1): 11-30.

Le Gof, Ž. (1997) Za jedan drugi Srednji vek. Vreme, rad i kultura Zapada. Novi Sad: Svetovi.

Le Goff, J. (1974) Srednjovekovna civilizacija Zapadne Evrope. Beograd: Jugoslavija.

Le Goff, J. (2009) Intelektualci u srednjem vijeku. Zagreb: Naklada Jesenski i Turk.

Le Goff. Ž. (2010) Da li je Evropa stvorena u srednjem veku. Beograd: Clio.

Livingstone, D. N. (2003) Putting Science in its Place: Geographies of Scientific Knowledge. Chicago and London: The University of Chicago Press.

McCarthy, D.E. (1996) Knowledge as Culture: The New Sociology of Knowledge. London and New York: Routledge.

Маринковић, Д., Шљукић, С. и Ристић, Д. (2014). „Од генеалогије ка гео-епистемологији: заокрет ка локалности простора, времена и знања“, Социолошки йреглед 48(3): 333-352.

Marinković, D. i Ristić, D. (2016) Ogledi iz geoepistemologije: prostor-prakse-moć. Novi Sad: Mediterran Publishing.

Marinković, D. and Ristić, D. (2016) “Foucault’s 'Hall of Mirrors区: investigation into geoepistemology“, Geografiska Annaler B: Human Geography 98(2): 83-96.

Marinković D. and Ristić, D. (2019) "Knowledge as Identity: An Essay in Genealogy", Society Register 3(1): 73-86.

Milenković, P. (2016) Škola Anala: između istoriografije i sociologije. Novi Sad: Mediterran Publishing.

Milić, V. (1986) Sociologija saznanja. Sarajevo: Veselin Masleša.

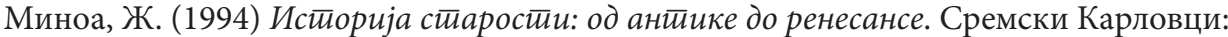
Издавачка књижарница Зорана Стојановића.

Minoa, Ž. (2008) Istorija samoubistva. Novi Sad: Mediterran Publishing.

Popić, T. (2007) „Oblikovanje srednjovjekovne stvarnosti - sociologija znanja i povijest“, Povijesni prilozi 33: 239-248.

Ristić, D. and Marinković, D. (2016) “The disciplinary society and the birth of sociology: A Foucauldian perspective”, Družboslovne razprave 32(83): 29-43.

Stiefel, T. (1977) “The Heresy of Science: A Twelfth-Century Conceptual Revolution”, Isis 68(3): 347-362. 
Šmit, K. (2011) Nomos zemlje. Beograd: Fedon.

Ven, P. (2013) Kada je naš svet postao hrišćanski. Novi Sad: Mediterran Publishing.

Wintle, M. (2013) “The History of the Idea of Europe: Where are We Now?", Perspectives on Europe 43(1): 8-13.

Weiler, H. N (2009) "Whose knowledge matters? Development and the Politics of Knowledge" in Entwicklung als Beruf. Baden-Baden: Nomos.

\title{
KNOWLEDGE IN THE MEDIEVAL EUROPE: CONTRIBUTION TO THE GENEALOGY OF UNIVERSITY
}

\begin{abstract}
In this article we assume that important genealogical lines of regionalization and institutionalization of public and anonymous (scientific) knowledge, began in Europe throughout $12^{\text {th }}$ and $13^{\text {th }}$ Centuries with the rise of universities. In the space of Medieval Europe, process of institutionalization of knowledge was inextricably linked with politics, economy, geography and other social factors. Our aim in this article is to explain the connection between identity of Europe at the time and this process of institutionalization of knowledge. Although the first universities were different to some extent, they also shown many common features, still known today. We explain why the rise of universities in Europe was the consequence of the social imagery of the Middle Ages on the one side, and social conditions on the other. We particularly emphasize the importance of the social organization of feudal type and the importance of the "ThreeOrders Ideology" in the Medieval social imagery.
\end{abstract}

Keywords: knowledge, Europe, Middle Ages, university, genealogy 